\title{
PELATIHAN APLIKASI ONLINE SINGLE SUBMISSION UNTUK PEMBUATAN NOMER INDUK BERUSAHA UMKM DI KABUPATEN PRINGSEWU
}

\author{
Arum Arupi Kusnindar ${ }^{1}$, Dian Pratiwi ${ }^{2}$, Dewi Mariam Widiniarsih ${ }^{3}$ \\ ${ }_{1,2,3} \mathrm{FEB}$, Universitas Muhammdiyah Pringsewu \\ Email: arumkusnindar@gmail.com
}

\begin{abstract}
Abstrak: Kegiatan pengabdian kepada masyarakat ini didasari dengan di permudahnya perijinan untuk UMKM melalui aplikasi OSS. Namun, UMKM di Kabupaten Pringsewu yang memanfaatkan OSS masih sedikit. Kegiatan ini di lakukan bekerja sama dengan Dinas Koperindag Pringsewu dan bertempat di Aula Koperasi Sumarta dengan peserta sebanyak 15 UMKM Kabupaten Pringsewu. Kegiatan dimulai dengan tahap perencanaan dan koordinasi dengan Dinas Koperindag, Tahap Pelaksanaan terdiri dari kegiatan penyampaian materi dan langsung dilanjutkan dengan pengisian OSS. Hasil dari kegiatan ini adalah di dapatkannya ijin NIB untuk peserta pelatihan.
\end{abstract}

Kata Kunci: NIB, OSS, UMKM

\subsection{Pendahuluan}

Kabupetan Pringsewu mempunyai wilayah 725 KM2, terdiri dari 126 pekon (desa) dan 9 Kecamatan. Yaitu kecamatan Pardasuka, Ambarawa, pagelaran, Pagelaran Utara, Pringsewu, Gadingrejo, Sukoharjo, Banyumas dan adiluwih. Pada tahun 2020 jumlah UKM di Kabupaten Pringsewu sebesar 9.735 unit usaha. Dari 9.735 unit usaha UMKM yang ada hanya $30 \%$ nya yang sudah memiliki ijin usaha minimal Nomer Induk Berusaha (NIB).

Kegiatan pengabdian masyarakat ini di latar belakangi oleh peraturan Nomor 24 Tahun 2018 yang berkaitan dengan Pelayanan Perizinan Berusaha Terintegrasi Secara Elektronik yang bertujuan untuk memberikan kemudahan perijinan bagi koperasi dan UMKM melalui aplikasi Online Single Submissiin (OSS), namun pada kenyataannya UMKM yang sudah memanfaatkan aplikasi ii sangat sedikit di bandingkan dengan jumlah UMKM yang ada.

Berdasarkan hasil observasi melalui wawancara dengan dinas koperindag serta 10 UMKM yang berlokasi di Kecamatan Pringsewu terdapat beberapa faktor yang menyebabkan sedikitnya pemanfaatan OSS, yaitu terbatasnya staff di Koperindag yang bisa melakukan sosialisasi sedangkan jumlah UMKM sangat banyak, minimnya sosialisasi membuat banyak UMKM yang tidak mengetahui adanya aplikasi OSS.

Berdasarkan observasi tersebut maka tujuan dari kegiatan pengabdian masyarakat ini adalah memberikan pengetahuan mengenai peraturan yang terkait perijinan usaha UMKM serta memberikan ketrampilan dalam menggunakan Aplikasi OSS. Sehingga mereka mampu mengurus sendiri perijinan yang mereka perlukan sekaligus mendapatkan ijin Nomer Induk berusaha (NIB) langsung pada saat pelatihan. Diharapkan para peserta pelatihan juga akan memberikan informasi kepada UMKM lain sehingga ini akan menjadi salah satu bentuk sosialisasi lanjutan.

Kegiatan pengabdian yang berfokus pada penguatan UMKM ini merupakan tindak lanjut dalam penelitian yang dilakukan oleh Kusnindar (2018) yang menunjukan bahwa kontrbusi UMKM pada PDRB sangat kecil, walaupun 99\% unit usaha yang ada di Kabupaten Pringsewu termasuk dalam skala UMKM dan salah satu langkah penguatan yaitu dengan membuat usaha UMKM mempunyai ijin yang jelas dan lengkap sehingga menjadi bankable.

OSS adalah pelaksanaan dari Undang - Undang Nomor 11 tahun 2020 Tentang Cipta Kerja. OSS berbasis Risiko wajib di gunakan oleh pelaku usaha, Kementrian/Lembaga, Pemerintah Daerah, Administrator Kawasan Ekonomi Khusus (KEK), dan Badan Pengusahaan Kawasan Perdagangan Bebas Pelabuhan Bebas (KPBPB). OSS merupakan 
bentuk dari reformasi pada bidang perijinan usaha secara online di sesuaikan dengan besar kecilnya skala usaha.

Sehingga, sasaran dari kegiatan pengabdian ini adalah UMKM yang ada di kabupaten Pringsewu. Karena keterbatasan ruang serta kondisi pandemi yang mengharuskan peserta harus jaga jarak, maka pelatihan hanya di berikan kepada 15 UMKM yaitu; .Sri Subekti UKM Fajar Agung, Irwan IKM Pringsewu, Paiman UKM amrih Sentosa, Harsono UKM Bina Sejahtera, Ani Puspita UKM Sale Az zahra, Setiowati BMT AL Ihya, Asih Kopi Isyarat, Annisa Anwarul Huda, Bekti Bean Bag Cikoko, Nurjannah Donat Khataku, Nurul Empek Empek Fafa, Feri Tepung Serbaguna, Ning Peternakan Ayam, Eli Kopi Benny dan Andry Bengkel Mr Se'cure.

Manfaat dari kegiatan pengabdian kepada masyarakat ini tentu saja akan sangat membantu UMKM untuk dapat "naik kelas". Dengan memiliki ijin, maka unit usaha bisa mendapatkan kredit dari perbankan, serta dapat di pantau dan di dampingi oleh pemerintah setempat. Ijin juga menjadi syarat jika usaha tersebut akan melakukan ekspor serta memperluas jaringan pemasaran secara nasional. Kegiatan ini juga menjadi salah satu cara sosialisasi mengenai kemudahan perijinan yang nantinya akan di teruskan kepada UMKM lain.

\subsection{Metode}

Kegiatan pengabdian kepada masyarakat ini dilakukan dengan bekerjasama dengan Dinas Koperindag Kabupaten Pringsewu Bidang Koperasi dan UMKM serta salah satu peserta yang bersedia meminjamkan tempat untuk kegiatan pelatihan. Metode pelaksanaan dilakukan dengan bentuk pelatihan yang dilakukan dengan dua tahap, yaitu tahap pemberian materi dan tahap praktek secara langsung menggunakan aplikasi OSS.

Pelaksanaan kegiatan di laksanakan pada hari Rabu, 16 Juni 2021, bertempat di aula lantai dua koperasi Sumarta Kecamatan Pringsewu.

Pada tahap pertama, yaitu pemberian materi kepada peserta. Materi di sampaikan oleh narasumber Arum Arupi Kusnindar dan berisi tentang latar belakang di adakannya kegiatan dan manfaat mempunyai ijin. Materi di sampaikan selama 45 menit secara luring. Latar Belakang di adakannya kegiatan pengabdian ini adalah masih sedikit nya UMKM tahu dan mampu memanfaatkan OSS untuk pengurusan ijin usahanya. Mengingat pentingnya ijin bagi perkembangan usaha maka kegiatan pelatihan ini menjadi sangat berguna dan sangat penting untuk segera di laksanakan. Materi juga di berikan mengenai manfaat mempunyai ijin yaitu agar secara legal dapat terpenuhi, bisa melakukan ekspor dan layak untuk mendapatkan kredit perbankan maupun investor non perbankan.

Tahap kedua adalah praktek secara langsung menggunakan komputer yang di sediakan maupun laptop peserta. Narasumber dalam tahap kedua di pimpin oleh Dian Pratiwi dan Dewi Mariam Widiniarsih bersama dengan pegawai dari Dinas koperindag Kabupaten Pringsewu. Perlu lebih dari satu pendamping karena sebagian peserta masih awam dengan aplikasi OSS dan bahkan awan dengan pemakaian laptop, sehingga perlu di dampingi satu demi satu.

\subsection{Hasil dan Pembahasan}

Hasil dari kegiatan pengabdian kepada masyarakat ini adalah bertambahnya jumlah UMKM yang mempunyai NIB, tumbuhnya kesadaran bagi UMKM mengenai pentingnya ijin usaha, dan akan memberi motivasi kepada UMKM lain mengenai kemudahan dalam mengurus ijin usaha UMKM NIB menjadi syarat utama bagi UMKM dalam proses - proses ijin yang lain seperti PIRT, Halal, BPOM dan Merek ( Haki untuk Merek dagang).

Pembahasan pertama berkaitan dengan materi dasar mengenai pentingnya perijinan, manfaat perijinan, dan jenis perijinan lain yang di butuhkan sebuah unit usaha selain ijin NIB yang di buat di dalam kegiatan pengabdian ini seperti PIRT (khusus untuk produk makanan), 


\section{BAGIMU NEGERI : JURNAL PENGABDIAN MASYARAKAT}

P-ISSN : 2548-8651 | E-ISSN : 2548-866X

Email : ejournal@umpri.ac.id

Halal BPOM dan Haki untuk merek dagang. Juga di informasikan beberapa program pengurusan ijin Halal dan BPOM yang di inisiasi oleh Kementrian Koperasi dan UMKM secara gratis.

Berikut adalah tampilan pada aplikasi OSS yang di ajarkan kepada peserta
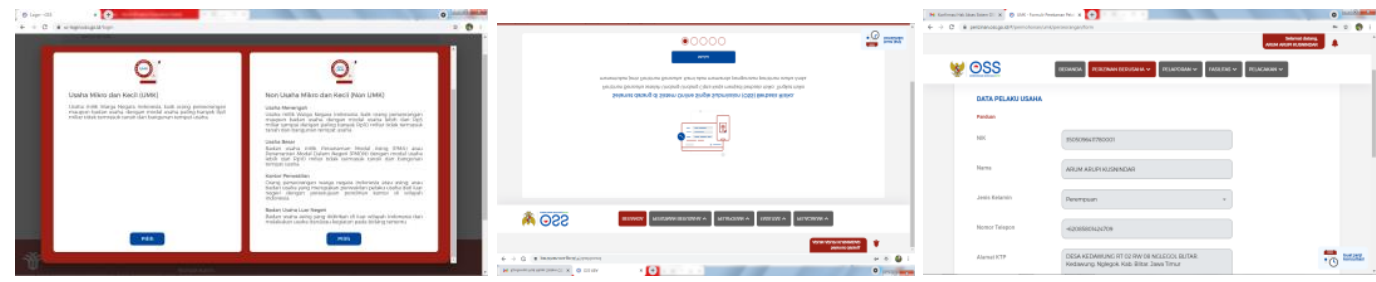

Proses selanjutnya adalah proses pelatihan dan pendampingan secara langsung para peserta dalam mengoperasikan aplikasi OSS sekaligus, proses membuat akun atau mendaftar dalam aplikasi, aktivasi akun, lalu di lanjutkan dengan memasukan data diri dan NPWP. Kemudian mengisi data usaha seperti jenis usaha, jumlah karyawan, jumlah modal, serta memilih KBLI (Klasifikasi Baku Lapangan Usaha Indonesia). KBLI adalah pengklasifikasian aktivitas/kegiatan ekonomi Indonesia yang menghasilkan produk/output, baik berupa barang maupun jasa berdasarkan lapangan usaha untuk memberikan keseragaman konsep, definisi, dan klasifikasi lapangan usaha. Terdapat 21 Lapangan usaha yang nanti akan di bagi lagi kedalam setiap jenis usaha secara detail.

Setelah proses input KBLI selesai, maka ijin usaha yang berupa Nomer Induk berusaha (NIB) elektronik sudah keluar dan dapat di cetak sendiri. Namun, NIB elektronik ini perlu di aktifkan dengan membawa dokumen ini ke Dinas Satu Pintu Kabupaten Pringsewu di Komplek Perkantoran Pemda atau di kenal dengan istilah Pemenuhan Komitmen. Proses pelatihan hanya sampai terbitnya NIB, proses Pemenuhan Komitmen di lakukan secara individu oleh peserta.

Berikut adalah dokumentasi pelatihan melalui komputer
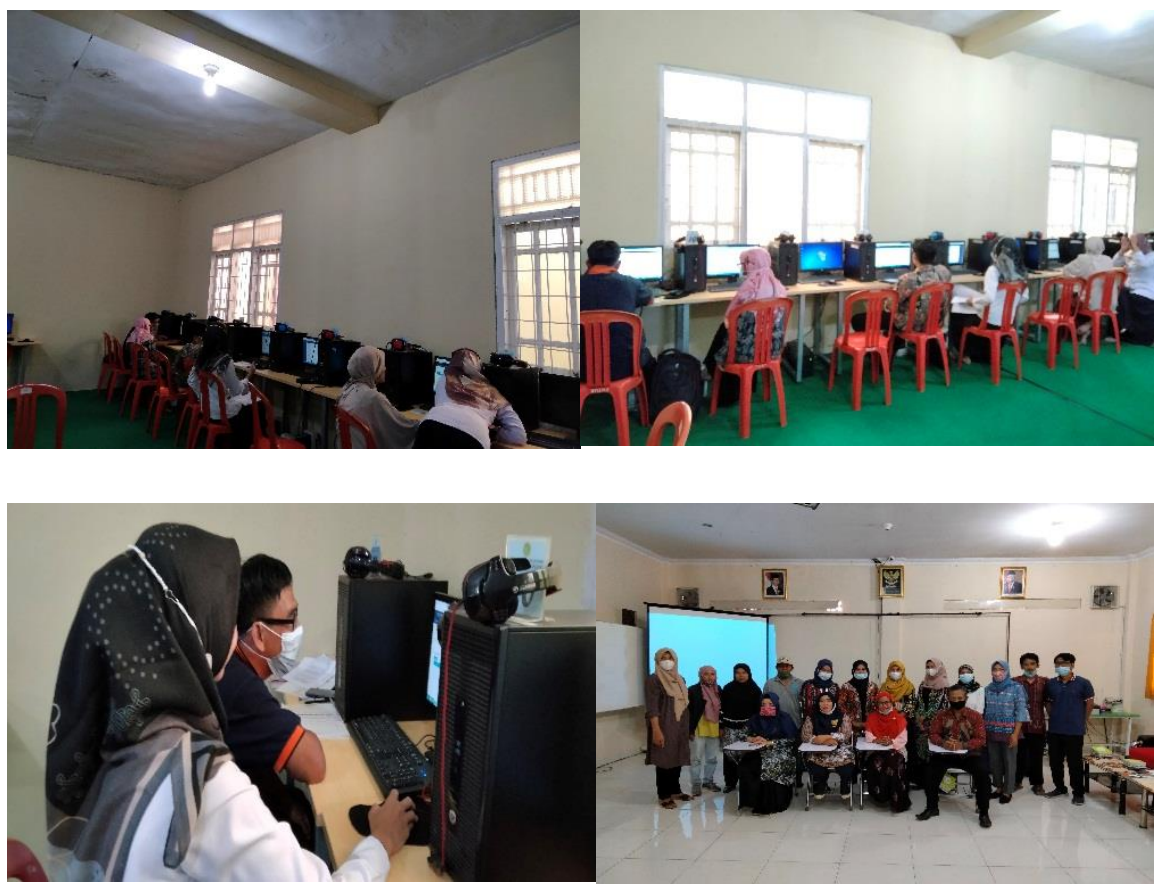
Kendala yang di temui selama pelatihan adalah kesulitan beberapa peserta dalam mengoperasikan komputer, sehingga perlu di damping terus menerus. Aplikasi perlu di aktivasi melalui email,sedangkan beberapa peserta belum mempunyai email. Sehingga, pendamping harus membuatkan email terlebih dahulu.

\subsection{Simpulan dan Saran}

Ijin usaha (NIB) wajib di miliki oleh semua pelaku usaha. Peran civitas akademika sangat penting untuk mempercepat proses sosilisasi dan pelatihan. Pelaku usaha kecil tidak dapat melakukan sendiri walaupun sudah di bekali dengan buku panduan karena mereka masih sangat awam terhadap teknologi. Maka dari itu, sekali lagi peran civitas akademika sangat penting untuk mengatasi kendala ini. Untuk proses kegiatan selanjutnya, di sarankan pendamping yang lebih banyak sehingga bisa satu pendamping untuk dua peserta. Sehingag proses pengisian aplikasi OSS menjadi lebih cepat.

\section{Daftar Rujukan}

Arrum, D. A. (2019). Kepastian Hukum Dalam Perizinan Berusaha Terintegrasi Secara Elektronik (Online Single Submission) di Indonesia. Jurist-Diction, 2(5), 1631-1654.

Kusnindar, A. A. (2018). PROFILING UKM DI KABUPATEN PRINGSEWU SEBAGAI BASIS MENCIPTAKAN MODEL PEMBERDAYAAN UKM YANG TEPAT SASARAN. Jurnal Ilmiah Ekonomi Manajemen: Jurnal Ilmiah Multi Science, 9(1), 117.

Kusnindar, A. A. (2019). PENDAMPINGAN PERIJINAN UMKM DI KABUPATEN PRINGSEWU. Jurnal Pengabdian Masyarakat Bumi Raflesia, 2(2).

Nurhidayati, N., Sugiyah, S., Syahyuni, D., \& Wianti, W. (2021). Merubah Tantangan Sebagai Peluang di Masa Pandemi Bagi Komunitas UMKM Naik Kelas Kota Bekasi. Jurnal Abdimas Ekonomi dan Bisnis, 1(1), 6-11.

Robby, U. B. I., \& Tarwini, W. (2019). Inovasi Pelayanan Perizinan Melalui Online Single Submission (OSS) Studi Pada Izin Usaha di Dinas Penanaman Modal dan Pelayanan Terpadu Satu Pintu (DPMPTSP) Kabupaten Bekasi. Administratio: Jurnal Ilmiah Administrasi Publik dan Pembangunan, 10(2), 51-57. 